\title{
Participation, Discouraged Workers and Job Search: Evidence for Kosova ${ }^{1}$
}

\author{
By Avdullah Hoti*
}

In this paper, we investigate the labour supply determinants in Kosova, a high unemployment and transition economy. Our approach takes into account demand-side restrictions of labour supply that are typical in high unemployment economies and pays particular attention to gender differences. We assess the appropriateness of the ILO guidelines in determining an individual's labour force status in developing/high unemployment economies, such as Kosova. In addition, we investigate the determinants of engaging in job search and find evidence that the more educated show a stronger attachment to the labour market. This is the first systematic study of these issues in this post-socialist and post-conflict economy.

Keywords: labour supply, discouraged workers, transition economies, Kosova

\section{Introduction}

Following the regime change in the European Transition Countries (ETCs), employment, output, wages and prices suddenly ceased being set by central planners and became determined by market forces (Blanchard, 1997; Roland and Verdier, 1999; Svejnar 1999; Bruno, 2006; Kornai, 2006). These developments brought profound changes in the economic behaviour of individuals residing in these countries. The labour force participation (LFP) rate in ETCs prior to 1989 was higher than their level of economic development would predict, which was thought to be due to central planners providing subsidised childcare that reduced the costs of employment for mothers, kept real wages low and enforced laws obliging all eligible adults to work (Chase, 1995).

Kosova was one of the last countries to embark on the road of transition to a market economy (Hashi, 2001). Before 1990, it was the poorest region in the former Yugoslavia with a per capita social product of a quarter of the Yugoslav average in 1989 (Bevc, 1993). During 1990-1995, GDP contracted by 50 percent compared to its pre-transition level. Since emerging from the military conflict in 1999 and a decade of disinvestment, GDP is recovering and has now reached the level of around $€ 1,000$ in per capita. However, it remains the lowest of all SEE countries (see data from WIIW, 2007).

Labour market developments in Kosova following the regime change are different in many respects from those found in other transition economies. In

\footnotetext{
* Associate Professor, University of Prishtina, Kosovo.

1 The author would like to thank Professor Nick Adnett and Jean Mangan (Staffordshire University, UK) for very useful comments
} 
the early 1990s, some 145,000 workers (about 60 percent of employment in 1989) were dismissed from their jobs. Kosova is known for its young population and large-scale emigration, both of which influence the size and the age composition of its domestic labour force. Nearly one-third of the population is under the age of 15 , implying a large number of new entrants into the labour force each year. As a consequence of its recent history, young population and persistent high unemployment, approximately 20 percent of the population (that is half a million people) are emigrants, whose remittances are estimated at the level of 13 percent of GDP (Moalla-Fetini et al., 2005; BPK, 2006).

Kosova suffers from chronic labour market failure, with the young, females and the long-term unemployed bearing a disproportionate burden of the costs of this failure. The unemployment rate that is estimated at around 40 percent (SOK, 2005) is predominantly long-term ( 88 percent of the unemployed) and the unemployed are mainly youths of age 15-24 (66 percent). The employment-to-population ratio of 30 percent is relatively low compared to that in neighbouring countries. Based on the Riinvest Household and Labour Force Survey (HLFS), the LFP rate is estimated at 58 percent with large gender, urban-rural and education related differences (see data in Table A1 in Appendix).

In this paper, concentrating upon the case of Kosova we investigate the determinants of labour supply. The analytical framework that we utilise takes full account of the distinctive features of the Kosovan labour market. In section 2 , we introduce the theory and critically assess previous empirical approaches to estimating the labour supply function. In Section 3, we explain our estimation strategy and in Section 4 we report our findings paying particular attention to gender and urban/rural differences as these raise specific developmental concerns in Kosova. In Section 5, we assess the appropriateness of the ILO guidelines in determining an individual's labour force status in developing/high unemployment economies. We investigate if the discouraged workers (i) can be statistically differentiated from the rest of the inactive population and (ii) their similarities with the ILO unemployed. We also examine the determinants of engaging in job search, again concentrating upon differences between the discouraged and ILO unemployed workers. In Section 6 , we consider the policy implications of our findings, which also suggest the need for a different analytical framework to analyse the labour market in Kosova. The data used in the empirical investigations comes from the Riinvest HLFS, which we explain in Section 3.

\section{Theory and some Evidence on Labour Supply Function}

Conventional theory views the labour supply as determined by numerous individual and household level decisions on both participation and hours of work. The typical model used is the static neoclassical model of labour-leisure choice, which examines the effect of wage and non-labour incomes on the 
decision to supply labour to the market. Killingsworth and Heckman (1986), Pencavel (1986) and Blundell and Macurdy (1999) provide a review of different approaches of modelling labour supply. This simple static neoclassical framework is often extended to include other household members into the utility function as labour supply decisions are typically made in the context of decisions taken by other household members (as explained by the income-pooling hypothesis whereby all household members share household incomes) (Apps and Rees, 1997; Beninger and Laisney, 2002; Devereux, 2004; Blundell et al., 2005). Data limitations often cause the static model to be favoured in empirical investigation of the determinants of labour supply. ${ }^{1}$ Below critically assess the conventional empirical approaches used to estimate such a labour function and present some related evidence.

\section{Empirical Approaches to estimating the Labour Supply Function}

Differences in the approaches to estimating the static model of labour supply seem to reflect differences in data availability. Our literature review identified three main approaches to estimating the labour supply function: (i) estimations regarding hours of work decisions, (ii) multiple discrete choices of labour supply decisions (where choices represent the categories of working hours) and (iii) the binary choice approach where labour supply choice is defined as participation versus non-participation.

Studies that employ the first approach usually control for non-participation (i.e. corner solution of $h=0$ ), that is in line with Heckman's (1993) argument on the importance of the theoretical distinction of labour supply choices (participation versus non-participation) and hours of work supplied. In this approach, an individual's hours of work $h_{i}$ (per unit of time) is regressed on their own wage $\left(w_{i}\right)$, non-labour income $\left(y_{i}\right)$ and other control variables $\left(A_{i}\right)$ :

$$
\begin{array}{ll}
\mathrm{h}_{\mathrm{i}}=\mathrm{f}\left(\mathrm{w}_{\mathrm{i}}, \mathrm{y}_{\mathrm{i}}, \mathrm{A}_{\mathrm{i}}, \varepsilon_{\mathrm{i}}\right) & \text { if and only if } \quad \mathrm{w}>\mathrm{w}^{*} \\
\mathrm{~h}_{\mathrm{i}}=0 & \text { if } \mathrm{w} \leq \mathrm{w}^{*}
\end{array}
$$

where $\varepsilon_{i}$ is the error term and $w^{*}$ is the reservation wage. In almost all empirical estimations of this model, the Tobit model is employed to handle the corner solution of $h_{i}=0$.

Heckman (1993) argues that when deciding to supply labour to the market, an individual makes two decisions: (i) participation that determines whether we observe $h_{i}=0$ and (ii) hours of work that is the size of $h_{i}$ given that $h_{i}>0$. In the Tobit framework, the direction of the effect of any explanatory variable on $h_{i}$ is the same with regard to $\operatorname{Pr}\left(h_{i}>0 \mid x_{i}\right)$ and $E\left(h_{i} \mid h_{i}>0, x_{i}\right.$, ) (see Wooldridge, 2002). This is a restrictive assumption, since a given explanatory variable may have an opposite effect on the probability of observing $h_{i}>0$ compared to its effect on the size of $h_{i}$ when $h_{i}>0$. This may be the case when the participation

\footnotetext{
${ }^{1}$ Models have also been developed which analyse the dynamics of labour supply over the lifecycle. These models assume that a person maximizes her utility taking into account lifecycle earnings and other related determinants of the labour force participation.
} 
decision is independent of how many hours to work, suggesting that the Heckman sample selection model is indeed the appropriate model for estimating labour supply elasticities.

In the second approach of multiple discrete choice of labour supply, multinomial models are utilised, whereby hours of work are reported in categories. The use of this approach is justified on the ground that there is little variations due also to demand-side restrictions in the observed hours of work variable even when it is reported as a continuous variable.

Finally, in the third approach the labour supply function is estimated by employing a binary choice model:

$$
\operatorname{Pr}\left(\mathrm{h}_{\mathrm{i}}>0 \mid \mathrm{w}_{\mathrm{i}}, \mathrm{y}_{\mathrm{i}}, \mathrm{A}_{\mathrm{i},}, \varepsilon_{\mathrm{i}}\right)
$$

In almost all such studies, participation is treated as synonymous with being in employment, reflecting the North American norm of low unemployment. As we argue below, equating labour supply to employment may not be appropriate in high unemployment economies. Despite advancements in the estimation procedures, there are still some conceptual problems in estimating a labour supply function. In all these approaches, it is assumed that workers are free to choose their hours of work and the observed hours of work reflect a labour supply decision. This implies that the desired/optimal hours of work $\left(h_{d}\right)$ that maximise the utility (given the budget constraint) are assumed to be equal to the actual hours of work $\left(h_{a}\right)$.

This assumption is too restrictive for the following reasons. First, even when there is a range of jobs offering different hours of work, workers are unlikely to be mobile due to their skills not being transferable across jobs. Second, information asymmetry usually characterises the labour market (say due to search costs). Third, there are demand-side restrictions regarding the choice of hours of work within jobs. Finally, particularly in high unemployment economies including Kosova, there are demand-side restrictions regarding the availability of jobs at the market wage.

A number of studies are now available supporting the view that at least part of unemployment does not represent leisure, but rather a constraint on labour supply due to the lack of demand for labour (Ham, 1982; Blundell et al., 1987; Kahn and Lang, 1991; Kuismanen, 1997; Brown and Sessions, 2001). The observed high inactivity (such as in the Kosovan labour market) implies that joblessness may not be attributed to the reservation/asking wage exceeding the offered wage (although this cannot be ruled out completely), but it is rather a matter of jobs not being available at the market wage. This implies that for a significant number of unemployed individuals, the actual hours of work being zero does not reflect their labour supply decisions.

There is no evidence available for transition or developing economies regarding the gap between the actual and desired hours of work. For Canada, Kahn and Lang (1991) find a considerable difference between actual and desired hours of work (a third of the sample of female workers want to work more than they actually work, while some 17 percent want to work less). For 
the Netherlands, Euwals and van Soest (1999) find that on average the desired hours of work per week for men and women are 11.5 percent and 10.5 percent higher than their actual hours of work respectively. Brown and Sessions (2001) find for Britain that more than a third of the employed sample would like to work less, while only 4 percent would like to work more than they actually work.

Given the discussion above, when estimating the labour supply function, it may be incorrect to specify other variables constraining an individual's behaviour to be the same when $h_{a}=h_{d}$ as when $h_{a}<h_{d}$, since the estimates might be misleading as far as policy implications are concerned. This problem was emphasised in the early literature of labour supply determinants (Pencavel, 1986), but very few studies acknowledge this or make this distinction in the empirical estimation. The limited empirical evidence suggests that the estimated coefficients from the sample where $h_{a}=h_{d}$ are significantly different compared to estimates from the sample where $h_{a}<h_{d}$ (Kahn and Lang, 1991; Conolly, 1997; Brown and Sessions, 2001).

\section{Evidence from Transition and developing Economies}

There is limited evidence regarding the determinants of labour supply in ETCs. Siliverstovs and Koulikov (2002) estimate a logarithmic specification of Equation (1) for married females in Estonia and find that the wage elasticity of hours supplied per week is positive (0.53), while the non-labour income effect is insignificant. They also find a significant negative effect of the presence of small and teenage children and a significant positive effect of working experience. Mizala et al. (1999) find for Chile that education (as a proxy for the market wage) is more important for females than for males in determining hours of work per week. The presence of children inhibits the labour supply of women, while for males it has a positive effect on hours of work per week. For females, Mizala et al. find that the change in the labour supply with a change in the explanatory variables is largely reflected in the decision to participate in the labour force rather than changing hours of work supplied, while for males the change is more in terms of hours of work.

Some studies use a binary choice model of labour supply function (participation vs. non-participation) as described by Equation (2) and take participation as synonymous with employment. Saget (1999) finds for the married women in Hungary a positive effect of the wage (in a model that includes the predicted wage for the non-employed women) on the probability of participation and no effect of earnings of other family members. Pastore (2005) finds for young Poles aged 15-30 that education is an important determinant of the probability of participation. Bardasi and Monfardini (2005) find that the probability of participation of Polish women decreases with the number of children. Chase (1995), using a dataset for the Czech Republic and Slovakia during and after communism, finds that in the Czech Republic the own-earnings effect on the probability of participation fell during transition, while it rose in Slovakia. He also finds that the negative effect of children on 
women's labour supply increased during transition, which coincides with the decrease in subsidies to childcare.

To summarise, the limited evidence for transition economies confirms the expected pattern of a positive effect of wage (or education that is a proxy for wage) and a negative effect of costs of employment on labour supply decisions. However, as we noted above, the observed labour supply of individuals when unemployment is high (and probably job offers are not available at the market wage) might not reflect utility maximising behaviour, which in the neoclassical framework is the underlying assumption when estimating the labour supply.

\section{Data and the Estimation Strategy}

In this section, we briefly discuss the Riinvest HLFS data and explain our estimation strategy. The Riinvest HLFS was conducted in December 2002. The unit of observation was the household and the sample was representative of urban and rural areas and the 7 main regions of Kosova. The sample consisted of 1,252 households (randomly selected after sample stratifications) with 8,552 members that is 0.45 percent of the population in Kosova. The survey questionnaire included questions regarding the demographic labour market information of each household member, household's incomes and expenditures, household members abroad, the household land etc.

Figure A1 in Appendix shows how an individual's labour force status is determined according to this survey, which complies with international labour standards (ILO, 1982; ILO 2005). The LFP rate estimated at 58 percent is especially low for females (Table A1). Following our discussion above, although we have data from the Riinvest HLFS survey, the model presented by Equation (1) for the hours of work seems inappropriate in our case as only 30 percent of the sample of working age individuals in Kosova are employed (i.e. have $h_{i}>0$ ). From the practical point of view, it seems inappropriate to consider 70 percent of the sample as described by the corner solution of $h_{i}=0$.

We estimate a binary choice model of labour supply as described by Equation (2). Unlike those studies that consider participation to be equivalent to employment, we define participation as the sum of employment and unemployment. Note that for the employed in Kosova the desired hours of work are positive $\left(h_{d i}>0\right)$ by definition. Following our discussion above regarding the desired versus actual hours of work, we assume that $h_{d i}>0$ for the unemployed as well since they engage in job search indicating that they would like to work. The inactive persons are considered as non-participants with $h_{d i}=0 .{ }^{l}$ Following this approach, we account for the demand-side restrictions in the labour supply decisions. Therefore, the model that we estimate is a probit model:

\footnotetext{
${ }^{1}$ Later we investigate empirically if this assumption applies to all of the inactive population.
} 


$$
\operatorname{Pr}\left(\mathrm{h}_{\mathrm{di}}>0 \mid \mathrm{A}_{\mathrm{i}}, \mathrm{H}_{\mathrm{i}}, \mathrm{Z}_{\mathrm{i}}, \varepsilon_{\mathrm{i}}\right)
$$

where $A_{i}, H_{i}$ and $Z_{i}$ stand for personal, household and contextual characteristics and $\varepsilon_{\mathrm{i}}$ is the usual error term. In the estimation, the dependent variable $h_{d i}=1$ if in the labour force (employed and unemployed) and $h_{d i}=0$ if inactive. We exclude those in full-time education giving 4,460 observations on individuals of age 16-64.

The three categories of explanatory variables are identified in Table 1. Conventionally, the educational dummies ${ }^{1}$ proxy for the potential wage as well as the probability of getting employment (because when unemployment is high the bargaining position of employees is expected to be weaker and the unemployed are likely to trade-off lower wages for a more secure employment). Age and age squared proxy the changing price of leisure over the life cycle as explained by the intertemporal substitution hypothesis. The dummy for marital status controls for the effect of family obligations as well as the effect of culture and attitudes toward work. A dummy for females of age 25-40 controls for the effect of females engaging in childbearing activities and can be thought of as accounting for some of the opportunity costs of employment. ${ }^{2}$

Table 1. The Explanatory Variables used in the Estimations of the Determinants of Labour Force Participation

\begin{tabular}{|c|c|}
\hline Explanatory variables & Definition of variables \\
\hline \multicolumn{2}{|l|}{ Personal characteristics } \\
\hline Age & Age of the respondent \\
\hline Age squared & Age squared \\
\hline Education & $\begin{array}{l}\text { Dummies: less than upper-secondary (omitted), } \\
\text { upper-secondary and higher }\end{array}$ \\
\hline Marital status & Dummy $=1$ if married, 0 otherwise \\
\hline Female of age $25-40$ & Dummy $=1$ if true, 0 otherwise \\
\hline \multicolumn{2}{|l|}{ Household characteristics } \\
\hline A household member is abroad & Dummy $=1$ if true, 0 otherwise \\
\hline Household labour incomes & $\begin{array}{l}\text { In per capita terms ( } € / \text { month) net of own wage if } \\
\text { employed: (incomes from salary, from working on } \\
\text { the family farm and incomes from family business }\end{array}$ \\
\hline Household non-labour incomes & $\begin{array}{l}\text { In per capita terms ( } € / \text { month): other household } \\
\text { incomes not included above }\end{array}$ \\
\hline \multicolumn{2}{|l|}{ Contextual characteristics } \\
\hline Residence & Dummy $=1$ if from urban areas, 0 otherwise \\
\hline $\begin{array}{l}\text { Regional dummies or regional } \\
\text { unemployment rate }\end{array}$ & $\begin{array}{l}7 \text { regions (omitted dummy for the region of } \\
\text { Prishtina) }\end{array}$ \\
\hline
\end{tabular}

\footnotetext{
${ }^{1}$ Some 0.5 percent of the sample did not report their education level. They are included in the reference category of less than upper-secondary education. As Cameron and Trivedi (2005) suggest, we could have applied listwise deletion for these observations, since they represent a small proportion of the total sample. But, given that primary and lower-secondary education is compulsory then it is very likely that these individuals have completed at least this level of education. This is likely to be the case since most of those individuals with missing data on their education level are above 50.

${ }^{2}$ A better way to test for this would have been by including a variable for the number of children, but this information cannot be constructed from our dataset.
} 
Variables related to household characteristics bring this perspective into the decision to supply labour to the market. The dummy on having a household member abroad is expected to test for the effect of remittances on labour supply decisions of non-migrant household members. Based on the neoclassical model of labour-leisure choice, remittances shift the budget line upwards and assuming that leisure is normal good then they reduce the labour supply of non-migrant household members (i.e. an income effect). However, in transition and developing countries characterised by an underdeveloped credit market, remittances are thought to be an important source of financing entrepreneurial projects. In line with this, some studies find that remittances increase the propensity of some non-migrant household members (males in particular) to engage in self-employment (Funkhosuer, 1992; Konica and Filer, 2005; Amuedo-Dorantes and Pozo, 2006).

Regarding household incomes, our data allow us to distinguish between household labour and non-labour incomes. The regional dummies and the urban versus rural dummy account for any regional-specific effect in labour supply decisions. We expect that those from the region of Prishtina (the capital city) are more likely to participate in the labour force due to their higher chances of getting jobs. However, those from the western and southern regions (where agriculture is an important activity and engages many household members) are also more likely to participate compared to other regions. These regional dummies may be thought of as capturing any discouragement effect among the non-employed workers in their decisions to supply labour to the market. Given that when employed urban residents tend to hold formal fulltime jobs, we would expect that education has a larger effect on their likelihood of participation compared to rural residents. To test for this we construct interactive dummies between residence and other explanatory variables.

Table A2 in the Appendix gives the mean of the explanatory variables for the whole sample, for those in the labour force and those inactive. There are three important observations from this data that are in line with our discussion above. First, those with higher potential wages and higher chances of getting a job (as proxied by the education level) are more likely to be in the labour force. Second, persons out of the labour force tend to be from households with higher non-labour incomes per capita. Third, females are less likely to participate, which is in line with their observed lower educational level (that affects their potential wages) and higher opportunity costs of employment (childcare).

\section{Findings}

In this section, we discuss our findings from estimating Equation (3). Given the observed large gender differences in the labour market and our prior expectations regarding different effects of explanatory variables on labour supply of males and females explained above, we estimate separate regressions by gender. Findings are presented in Table 2 . The estimated coefficients on age and its squared value have the expected signs and are significant for males and 
females, giving the normal concave shape of the LFP curves with respect to age. We have insufficient evidence to reject the null hypothesis of similar shapes of the LFP curves with respect to age for urban and rural residents.

Table 2. Estimates from the Probit Model for the Labour Force Participation. The Dependent Variable Equals 1 if in the Labour Force (employed or unemployed) and 0 if Inactive

\begin{tabular}{|c|c|c|c|c|}
\hline \multirow{3}{*}{ Explanatory variables } & \multirow{2}{*}{\multicolumn{2}{|c|}{$\begin{array}{c}\text { Males } \\
{[1]}\end{array}$}} & \multirow{2}{*}{\multicolumn{2}{|c|}{$\begin{array}{c}\text { Females } \\
{[2]}\end{array}$}} \\
\hline & & & & \\
\hline & Coeff. & $\mathrm{Z}$ & Coeff. & $\mathrm{Z}$ \\
\hline Constant & $-2.691^{* *}$ & - & $-1.762^{* *}$ & - \\
\hline \multicolumn{5}{|l|}{ Personal characteristics } \\
\hline Age & $0.215^{* *}$ & 8.64 & $0.101^{* *}$ & 3.50 \\
\hline Age squared & $-0.003^{* *}$ & - & $-0.002^{* *}$ & - \\
\hline Upper-secondary education & $0.317^{* *}$ & 3.02 & $0.569^{* *}$ & 6.17 \\
\hline Higher education & $0.361^{* * *}$ & 2.03 & $1.146^{* *}$ & 4.18 \\
\hline Married & -0.052 & - & $-0.621^{* *}$ & - \\
\hline Female age $25-40$ & & & -0.096 & - \\
\hline \multicolumn{5}{|l|}{ Household characteristics } \\
\hline A household member is abroad & -0.092 & - & $-0.178^{*}$ & - \\
\hline Household labour incomes per capita & 0.001 & 0.30 & $0.007^{* *}$ & 5.10 \\
\hline Household non-labour incomes per capita & - & - & -0.001 & - \\
\hline \multicolumn{5}{|l|}{ Regional dummies } \\
\hline Urban resident & 0.240 & 0.36 & -0.311 & - \\
\hline Prizren & 0.176 & 1.51 & 0.078 & 0.81 \\
\hline Peja & -0.064 & - & $0.239^{* *}$ & 2.38 \\
\hline Mitrovica & -0.011 & - & $0.413^{* * *}$ & 4.54 \\
\hline Gjilan & -0.071 & - & $0.305^{* *}$ & 2.97 \\
\hline Ferizaj & $0.224^{*}$ & 1.67 & 0.052 & 0.45 \\
\hline Gjakova & 0.259 & 1.49 & $0.296^{* *}$ & 2.23 \\
\hline \multicolumn{5}{|l|}{ Interactive dummies } \\
\hline Urban resident - Age & -0.043 & - & 0.034 & 0.80 \\
\hline Urban resident - Age squared & 0.0004 & 0.92 & -0.0004 & - \\
\hline Urban resident - Upper-secondary education & $0.472^{* *}$ & 2.92 & $0.443^{* *}$ & 3.34 \\
\hline Urban resident - Higher education & $0.862^{* * *}$ & 3.34 & $0.739^{* *}$ & 2.25 \\
\hline Urban resident - Married & $0.570^{* *}$ & 2.53 & 0.239 & 1.62 \\
\hline Urban resident - Female age $25-40$ & & & -0.196 & - \\
\hline Urban resident - A household member is abroad & $0.367^{*}$ & 1.86 & -0.217 & - \\
\hline Urban resident - Household labour incomes per capita & -0.002 & - & $-0.010^{* *}$ & - \\
\hline Urban resident - Household non-labour incomes per & $-0.004^{* *}$ & - & -0.002 & - \\
\hline Log likelihood & -825.8 & & - & \\
\hline Likelihood Ratio test, $\chi_{(25)}^{2}$ & $415.2^{\#}$ & & 666.7 & \\
\hline Pseudo R squared & 0.201 & & 0.214 & \\
\hline Mean dep. variable (observed) & 0.816 & & 0.419 & \\
\hline Sample size & 2,167 & & 2,293 & \\
\hline
\end{tabular}

${ }^{\#}$ Likelihood Ratio test, $\chi_{(23)}^{2}$ because of 23 coefficients males' regression equation.

$* * *, * *, *$ significant coefficient at 1,5 and 10 percent respectively.

In line with the evidence elsewhere, the estimated coefficients on educational dummies have the expected positive signs and are significant. The significant and positive coefficients on the interactive dummies between residence and education (for both genders) support our expectations of a greater role for education on the labour supply of urban residents compared to 
their rural counterparts. Our estimate indicates that being married lowers the likelihood of supplying labour to the market for females ceteris paribus, but no significant difference is found between urban and rural females. The estimated additional affect on marital status for urban males is positive and significantly different from the rural rate. For urban areas this provides some support for our expectations of an increased labour supply of married males to provide additional incomes for the extended family, which is also in line with the findings elsewhere (e.g. Mizala et al., 1999).

We do not find evidence for the expected negative effect on participation of females engaging in childbearing. Examining the descriptive statistics we find that 31 percent of households are composed of 8 members or more, while 17 percent have 10 members or more that eases the constraints of having children on females' labour supply, since older family members can take care of them. ${ }^{1}$

Having a household member abroad is estimated to affect negatively female' participation, as expected, though the coefficient is significant only at the 10 percent level. For males, the coefficient on the interactive dummy with urban residence is positive and significant, but again only at 10 percent level. Regarding the effect of household labour incomes, our findings for females is of an unexpected positive significant effect in rural areas, although for urban areas the interactive dummy is significant and negative. With regard to the expected negative effect of household non-labour incomes on participation, our estimates support this only in the case of urban males.

Findings on the regional dummies for males do not support our argument of higher participation of residents from the region of Prishtina. The coefficients on regional dummies for males are individually insignificant (based on the $t$-test) and also jointly insignificant $\left(\chi_{(6)}^{2}=9.60, \mathrm{p}=0.1428\right)$. For females, 4 out of 6 coefficients on regional dummies are significant and positive (based on the t-test), while the 6 of them are jointly significant $\left(\chi_{(6)}^{2}=27.90, p=0.001\right)$. In two of these cases (Peja and Gjakova that are among the western and southern regions) findings support our expectations of higher participation due to working in predominantly agricultural regions. Given that our sample is representative at the regional level, we have estimated the same regressions with regional employment-to-population ratios substituting for the regional dummies to capture the discouragement effect due to a more depressed labour market. The estimated coefficient was insignificant for both genders. Other coefficients did not change their significance level and hardly changed their size. This is an expected finding given the current regional boundaries encompass small distances and males can easily commute to take advantage of better employment chances or higher wages. While for females, there is some evidence that they are less likely to commute and their labour supply decisions are made within the regional context.

\footnotetext{
${ }^{1}$ We constructed an interactive dummy (not reported in Table 2) between marital status and female of age 25-40 to further examine this issue, but found no significant coefficient on this dummy.
} 
The size of the effect of explanatory variables on the probability of labour supply is shown in Table A3. Panel $A$ shows the (base) probability of labour force participation for an individual with given characteristics. Rural males and females have a higher probability of participation compared to their urban counterparts respectively. Panel $B$ shows the change in the probability of labour supply due to a change in some of the characteristics keeping others the same. An interesting finding is the large effect of education on participation for females in particular. Increasing the level of education from less than uppersecondary education to upper-secondary increases the probability of participation for urban males by 15 percentage points (from 0.60 to 0.85 ), for urban females by 27 percentage points, for rural males by 5 percentage points and for rural females by 21 percentage points. Note also the large decrease in the estimated probability of participating in the labour force for a 50 years old female (urban and rural females).

To sum up, unlike most of the studies reviewed above we define participation as being in employment or unemployment (which as explain above and in Figure A1, both follow ILO guidelines). This acknowledges the difference between actual (observed) and desired hours of labour supply, which takes into account the demand side constraints on labour supply. We find evidence for the expected concavity of LFP rate with respect to age. Findings also support the view that education affects positively the probability of labour supply and this effect is estimated to be larger for urban residents compared to their rural counterparts. In line with findings elsewhere, our estimate suggests that married females are less likely to participate than non-married females. For rural females, there is weak evidence for the expected negative effect of a household member abroad on the probability of labour supply. The expected negative effect of household non-labour income on labour supply is supported only for urban males.

\section{Discouragement Effect and Labour Supply in Kosova}

Although in the estimations above we assumed that $h_{d}>0$ (the desired hours of work are greater than zero) for the unemployed, a significant number of working age population are inactive. Included among them are persons not searching because they do not expect to find jobs (usually referred to as the discouraged workers), although they would like to work if jobs were available. Assuming that engaging in job search by the non-employed workers is endogenous to labour market conditions, we expect that in high unemployment economies the discouragement effect may be more pronounced.

In our analysis above, using the Riinvest HLFS data, we utilised the ILO guidelines of active job search criteria to divide the non-employed individuals into the unemployed and inactive (as shown in Figure A1). In this section, we assess the appropriateness of this approach in cases when unemployment is high. We run some statistical tests to consider if the discouraged workers are different from the rest of the inactive population and discuss the implications 
for the labour supply in Kosova if they are included in the active labour force. Finally, we investigate the determinants of engaging in job search.

\section{The Appropriateness of ILO Guidelines when Unemployment is high}

To facilitate the comparison of unemployment rates and other labour market indicators over time and across countries, the ILO has adopted guidelines that classify the working age population into employed $(E)$, unemployed $(U)$ and inactive (N) (ILO, 1982; ILO, 2005). These guidelines have been adopted by most countries (Byrne and Strolb, 2004). While the classification of $E$ is relatively straightforward, there are controversies regarding the division of the non-employed into $U$ and $N$. In the ILO (1982), a non-working person is considered as $U$ if he/she is: (i) not working, (ii) currently available for work, and (iii) seeking work. Otherwise he/she is considered as $N$. The implicit assumption in this framework is that these nonemployed individuals voluntarily decide not to search.

In the supply and demand model of competitive labour market equilibrium, the interaction between workers looking for the best job opportunities and employers attempting to maximise profits equalises the value of marginal product of labour across firms (Kingdon and Knight 2000; Borjas, 2005; Kingdon and Knight, 2006). The model considers job search as a rational behaviour since it leads to finding the job offer with the highest rewards. This is also desirable from the social point of view, because it contributes to achieving the allocative efficiency of resources. The decision to search is affected by search costs, the distribution of expected wage offers, the probability of finding another job offer, unemployment benefits etc. (Kingdon and Knight, 2006). However, in a high unemployment economy (such as Kosova), the probability of locating a job offer is low. Due to the search costs involved, some of the unemployed may stop searching and are considered as inactive by the ILO guidelines (i.e. the discouraged workers as explained by the discouraged-worker hypothesis). Kingdom and Knight (2002) argue, there are two main reasons why workers stop searching. The first is based on the socalled 'taste for unemployment' argument whereby non-working members of the household receive high intra-household transfers. The second reason relates to the search costs, which affect the poor individuals that cannot afford to continue searching in which case excluding them from the labour force underestimates the true extent of unemployment.

However, in practice it is difficult to clearly distinguish between personal and labour market related reasons for being a discouraged worker (Hussmanns et al., 1990; Suryadarma et al., 2005). The inclusion of the discouraged workers within the labour force is based on the argument that these workers are behaviourally similar to the unemployed (e.g. they tend to enter employment during an economic upturn). On the other side, discouraged workers show a similar (weak) degree of labour force attachment as other groups of individuals in the inactive population and hence the argument not to include them in the labour force. On balance, as our discussion below suggests, whether they 
should be included among the labour force or not remains an empirical question.

Even though the discouraged workers are likely to exist in any economy ${ }^{1}$, in developing countries with slack labour markets the incidence of discouraged workers is likely to be higher. Consequently, excluding them from the labour force affects significantly the estimated unemployment and inactivity rates and consequently may have important implications for policy. Reflecting this, in a limited number of countries both narrow (ILO definition) and broad (with the discouraged workers considered as unemployed) unemployment rates have been estimated (Byrne and Strolb, 2004; Kingdon and Knight, 2006).

\section{Discouraged Workers and their Implications for Labour Supply in Kosova}

We now investigate the presence of discouragement amongst the inactive population in Kosova and the implications for its labour supply. From the sample of 4,460 working age individuals, 29 percent are unemployed on the basis of ILO definition and 39 percent are inactive (Table 3).

Table 3. Unemployment and Inactivity Rates when the Discouraged Workers are treated as unemployed

\begin{tabular}{lccc}
\hline & $\begin{array}{c}\text { Abbreviation used } \\
\text { in the text }\end{array}$ & Nr. & Proportion \\
\hline & {$[1]$} & {$[2]$} & {$[3]$} \\
\hline & & 4,46 & \\
1. All population of age 16-64* & $E$ & 0 & 1.00 \\
1.1. Employed & $I L O-U$ & 1,42 & 0.32 \\
1.2. Unemployed (based on ILO guidelines) & $N$ & 1,72 & 0.29 \\
1.3. Inactive (based on ILO guidelines) & $N_{d}$ & & 0.39 \\
$\quad$ - The discouraged workers & $N_{\text {not-d }}$ & 1,42 & 0.18 \\
$\quad$ - Other inactive workers & & & 0.82 \\
2. The ratio of discouraged workers to ILO unemployed & & 0.11 \\
3. The ratio of discouraged workers to ILO active labour force & & 0.48 \\
4. The ILO defined unemployment rate & & 0.53 \\
5. Unemp. rate if discouraged workers are considered as & & 0.39 \\
6. Inactivity rate based on ILO guidelines & & 0.32 \\
7. Inactivity rate if $\mathrm{N}_{\mathrm{d}}$ are considered as unemployed & & & \\
Source of data: Riinvest HLFS of December 2002; * Emigrants and those in full-time \\
education are excluded.
\end{tabular}

Examining the reasons for not searching (given in Table A4), we find that 18 percent of inactive persons have answered "because I cannot find a job" which may indicate that they are discouraged workers. They constitute 23 percent of the ILO defined unemployed and 11 percent of the ILO defined labour force in Kosova. This is higher than in many OECD countries (OECD, 1995; Jones and Riddell, 1999), and supports our argument above that in high unemployment economies the discouragement effect among the non-employed

\footnotetext{
${ }^{1}$ The OECD (1995) finds that in 1993 they constituted 5.7 percent of the labour force in Italy, 3.1 percent in Sweden, 3 percent in Australia etc. Jones and Riddell (1999) find for Canada that the discouraged workers constitute 25-35 percent of the unemployed.
} 
individuals is more pronounced. If they are included among the unemployed, then unemployment increases from 48 percent (ILO definition) to 53 percent (broad definition) and the inactivity rate decreases from 39 to 32 percent.

To investigate whether it is more appropriate to include discouraged workers $\left(N_{d}\right)$ that we identified above among the labour force we consider whether they are close to the ILO unemployed $(I L O-U)$ or to the rest of inactive population $\left(N_{\text {not-d }}\right)$ in their characteristics. In columns 2,3 and 4 of Table 4 we present the mean of the variables used in the labour supply determinants for $N_{\text {not-d }}, N_{d}$ and $I L O-U$ respectively. This data suggests the $N_{d}$ tend to be more similar in most respects to $I L O-U$ than to $N_{\text {not-d. }}$. Females are over-represented both among $N_{d}$ and $N_{\text {not-d }}$ indicating their weaker attachment to the labour market compared to males.

Table 4. Findings from t-tests for the differences between (i) $N_{d}$ and $N_{n o t-d}$ and (ii) $N_{d}$ and ILO-U

\begin{tabular}{|c|c|c|c|c|c|c|}
\hline & \multirow{2}{*}{$\begin{array}{l}\text { Type } \\
\text { of test }\end{array}$} & \multicolumn{3}{|c|}{ Inactive individuals $(N)$} & \multirow{2}{*}{$\begin{array}{cc}I L O- & \mathrm{H}_{0}: \\
U & \mu_{3}=\mu_{2}\end{array}$} & \multirow{2}{*}{$\begin{array}{c}\mathrm{H}_{0}: \\
\mu_{3}=\mu_{4}\end{array}$} \\
\hline & & All $(N)$ & $N_{\text {not-d }}$ & $N_{d}$ & & \\
\hline \multirow[t]{2}{*}{ Variables } & & [1] & [2] & [3] & {$[4] \quad[5]$} & [6] \\
\hline & & $\mu_{1}$ & $\mu_{2}$ & $\mu_{3}$ & $\mu_{4}$ & \\
\hline Gender structure (males) & Proportion & 0.230 & 0.206 & 0.343 & \multicolumn{2}{|c|}{0.538 RejectedRejected } \\
\hline Average age & Mean & 38.41 & 39.88 & 31.51 & 30.45 Rejected & Not \\
\hline \multicolumn{7}{|l|}{ Age structure } \\
\hline $16-24$ & Proportion & 0.231 & 0.200 & 0.376 & \multicolumn{2}{|c|}{ 0.361 Rejected Not } \\
\hline $25-34$ & Proportion & 0.225 & 0.210 & 0.294 & 0.325 Rejected & Not \\
\hline $35-44$ & Proportion & 0.177 & 0.175 & 0.185 & 0.201 Not & Not \\
\hline $45-54$ & Proportion & 0.167 & 0.188 & 0.066 & \multicolumn{2}{|c|}{ 0.079Rejected Not } \\
\hline $55-64$ & Proportion & 0.201 & 0.227 & 0.079 & \multicolumn{2}{|c|}{ 0.034Rejected Reject } \\
\hline Marital status & Proportion & 0.725 & 0.752 & 0.594 & \multicolumn{2}{|c|}{0.537 Rejected Not $*$} \\
\hline \multicolumn{7}{|l|}{ Education } \\
\hline Average educational level (years) & Mean & 8.780 & 8.604 & 9.604 & \multicolumn{2}{|c|}{ 10.61 RejectedRejected } \\
\hline Less than upper-secondary & Proportion & 0.703 & 0.726 & 0.591 & \multicolumn{2}{|c|}{ 0.368RejectedRejected } \\
\hline Upper-secondary education & Proportion & 0.260 & 0.238 & 0.366 & \multicolumn{2}{|c|}{ 0.571 RejectedRejected } \\
\hline Higher education & Proportion & 0.030 & 0.027 & 0.043 & 0.061 Not & Not \\
\hline Residence (urban) & Proportion & 0.394 & 0.414 & 0.304 & \multicolumn{2}{|c|}{ 0.425RejectedRejected } \\
\hline \multicolumn{7}{|l|}{ Household incomes } \\
\hline Household incomes per capita & Mean & 60.35 & 63.72 & 44.51 & 49.34Rejected & Not \\
\hline Household labour incomes per & Mean & 36.95 & 39.18 & 26.44 & 30.34Rejected & Not \\
\hline HH non-labour income per capital, & Mean & 23.46 & 24.60 & 18.08 & 19.03 Not $*$ & Not \\
\hline A household member is emigrant & Proportion & 0.252 & 0.251 & 0.254 & \multirow{2}{*}{$\begin{array}{l}0.193 \\
1,309\end{array}$} & Rejected \\
\hline Observations & & 1,729 & 1,426 & 303 & & \\
\hline
\end{tabular}

Source of data: Riinvest HLFS of December 2002; ${ }^{*} \mathrm{H}_{\mathrm{o}}$ can be rejected at 10 percent level of significance.

We run a series of $t$-tests to examine if these observed differences are statistically significant. From column 5, the null hypothesis of equal means (or equal proportions) between $N_{d}$ and $N_{\text {not-d }}$ is rejected in 13 out of 17 cases. From column 6 , the null hypothesis of equal means between $N_{d}$ and $I L O-U$ is rejected only in 7 of the 17 cases. Therefore, we find evidence to conclude that: (i) the inactive individuals are not a homogenous group and the discouraged workers can be statistically differentiated from the rest of inactive population; and (ii) 
the discouraged workers are in many respects similar to the ILO unemployed and arguably they should be considered as unemployed rather than inactive.

\section{The Determinants of engaging in Job Searching}

A further analysis to establish whether $N_{d}$ and $I L O-U$ are also behaviourally a homogenous group is to examine differences in their transition probabilities from one labour market state to another over succeeding time periods. Due to the lack of data (our data is cross-sectional and the respondents are not asked regarding their previous labour market experience), we cannot investigate this research question. Note that unlike $N_{d}, I L O-U$ are engaged in job search and therefore show a stronger attachment to the labour market. Given our findings above that $N_{d}$ in Kosova are in many respects similar to $I L O-U$, then with our cross sectional data we investigate what determines an individual's decision to engage in job search. This provides an indication as to the behavioural similarities between these two groups of individuals. The model that we estimate is a probit model where the dependent variable equals 1 if the person is $I L O-U$ and 0 if $N_{d}$. The sample consists of $I L O-U(1,309$ observations) and $N_{d}$ (303 observations). Our choice of explanatory variables is guided by the theory of job search behaviour analysed in the previous sections and broadly correspond to those found in other similar studies. The variables are those that we have defined in our estimation of the determinants of labour force participation. ${ }^{1}$ Findings are presented in Table 5 separately for males and females.

Although the test results in the previous section indicated that $I L O-U$ and $N_{d}$ are in many respects similar, the estimates on the determinants of engaging in job search from Table 5 suggest that there are also some behavioural differences between them. For males only, the estimates suggest that the likelihood of engaging in job search increases with age (but at a decreasing rate). For females, this likelihood increases with education, but is only significant for those having completed upper-secondary education. Perhaps due to the stronger attachment to the labour market of males regardless of their education level, none of the coefficients on the educational dummies are significant. Consistent with findings on the determinants of labour supply summarised presented above, for females the estimates suggest that being married lowers the likelihood of engaging in job search ceteris paribus. Perhaps due to the search environment, urban females are more likely to engage in active job search compared to their rural counterparts. For females, three out of six coefficients of the regional dummies are significant, while for males only one of them is significant and then only at 10 percent level. We do not find a significant effect of household incomes (labour or non-labour) on the probability of engaging in job search.

\footnotetext{
${ }^{1}$ Due to not having many observations in each subcategory (in particular for $N_{d}$, ) we do not include interactive dummies between the residence and other explanatory variables. We rely only on the residence dummy that allows for different intercepts.
} 
Table 5. Estimates from the Probit Model for engaging in Active Job Search. The Dependent Variable Equals 1 if the person is ILO unemployed and 0 if Discouraged Worker

\begin{tabular}{|c|c|c|c|c|}
\hline \multirow[b]{2}{*}{ Explanatory variables } & \multicolumn{2}{|c|}{ Males } & \multicolumn{2}{|c|}{ Females } \\
\hline & Coeff. & t-test & Coeff. & t-test \\
\hline & {$[1]$} & & {$[2]$} & \\
\hline \multirow{2}{*}{\multicolumn{5}{|c|}{ Personal characteristics }} \\
\hline & & & & \\
\hline Age & $0.106^{* *}$ & 2.98 & 0.044 & 1.03 \\
\hline Age squared & $-0.002 * *$ & -3.48 & -0.001 & -1.02 \\
\hline Upper-secondary education & 0.162 & 1.21 & $0.412 * *$ & 3.60 \\
\hline Higher education & -0.008 & -0.03 & 0.398 & 1.35 \\
\hline Married & -0.001 & -0.01 & $-0.258 * *$ & -2.17 \\
\hline Female age $25-40$ & & & -0.115 & -0.82 \\
\hline \multicolumn{5}{|l|}{ Household characteristics } \\
\hline A household member is emigrant & -0.198 & -1.42 & -0.220 & -1.61 \\
\hline Household labour incomes per capita & 0.001 & 0.45 & 0.001 & 0.84 \\
\hline Household non-labour incomes per & 0.002 & 0.80 & -0.002 & -1.25 \\
\hline \multicolumn{5}{|l|}{ Regional dummies } \\
\hline Residence (urban) & 0.129 & 0.98 & $0.352^{* *}$ & 3.09 \\
\hline Prizren & -0.227 & -1.21 & 0.030 & 0.18 \\
\hline Peja & $-0.359 *$ & -1.81 & $0.405^{* *}$ & 2.12 \\
\hline Mitrovica & -0.025 & -0.13 & 0.131 & 0.89 \\
\hline Gjilan & -0.068 & -0.32 & $0.381 * *$ & 2.11 \\
\hline Ferizaj & -0.140 & -0.66 & -0.018 & -0.09 \\
\hline Gjakova & -0.086 & -0.25 & $1.019 * *$ & 2.22 \\
\hline Log likelihood & -291.5 & & -415.9 & \\
\hline Likelihood Ratio test, $\chi_{(16)}^{2}$ & $37.52 \#$ & & 68.02 & \\
\hline Pseudo R-squared & 0.061 & & 0.077 & \\
\hline Mean dependent variable & 0.871 & & 0.752 & \\
\hline Sample size & 808 & & 804 & \\
\hline
\end{tabular}

${ }^{\#}$ Likelihood Ratio test, $\chi^{2}{ }_{(15)}$ because of 15 coefficient in males' regression equation. $* * *, * *, *$ significant coefficient at 1,5 and 10 percent respectively.

To conclude, assuming that the job search behaviour is endogenous to labour market conditions then the ILO guidelines of defining the labour force status of the non-employed individuals may be inappropriate in high unemployment economies. The discouragement effect among the nonemployed workers in these economies is more pronounced. Relaxing the ILO guidelines or reporting both narrow and broad unemployment rate help to provide estimates of the true extent of unemployment.

\section{Conclusions and Policy Implications}

In this paper, we investigated the determinants of labour supply in Kosova. Our analyses suggested that the standard neoclassical framework of analysing individuals' labour market behaviour might be inappropriate in economies such as Kosova due to demand-side restrictions preventing individuals from making choices compatible with the utility maximisation assumption. Demand-side restrictions push large numbers of Kosovars into inactivity (i.e. the discouraged workers) that would otherwise be searching for jobs. Our analysis suggested 
that ignoring this aspect of the labour market may produce misleading estimates and therefore misinform policy choices that could have lasting consequences.

Our findings confirm those found elsewhere, that individuals with higher potential wages (as proxied by the education level) are more likely to supply labour to the market and that this effect is stronger for urban residents. For females, being married lowers the likelihood of participation, while for males it increases it. We find some weak evidence that having a household member abroad (as a proxy for remittances) lowers females' labour supply though for males this effect is insignificant. Females' labour supply is negatively affected by household labour income, while for males (as expected) this effect is not significant. We find significant regional differences in the labour supply of females, but not for males suggesting that that females are less mobile and unable to take advantage of more distant employment opportunities.

The possible presence of discouraged workers amongst the non-employed is frequently overlooked in the labour supply literature. The decision to engage in job search (and therefore being considered as unemployed rather than discouraged) is expected to be endogenous to the search environment. Whether these workers are considered as unemployed or inactive has an important impact on the estimated unemployment and inactivity rates and therefore has policy implications. In Kosova, we find that 18 percent of the inactive individuals might be more appropriately classified as discouraged workers. If they are considered as labour force participants then the ILO defined unemployment rate increases by 5 percentage points and the inactivity rate decreases by 7 percentage points. The discouraged workers are in many respects similar to the ILO unemployed. Investigating the determinants of engaging in job search (i.e. being ILO unemployed as opposed to being a discouraged worker), we find that overall males and the more educated show a stronger attachment to the labour market. Our advice is for national statistics to report both narrow (ILO definition) and broad (that accounts for the discouraged workers) unemployment rates.

\section{References}

Amuedo-Dorantes C, Pozo S (2006). Migration, remittances, and male and female employment. American Economic Review 96(2): 222-226.

Apps P, Rees R (1997). Collective labour supply and household production. Journal of Political Economy 105(1): 178-190.

Bardasi E, Monfardini C (2005). Women's labour force participation and transition, An empirical analysis on Poland. Centre for Household, Income, Labour and Demographic Economics: 07.

Beninger D, Laisney F (2002). Comparison between unitary and collective models of household labour supply with taxation. ZEW: 65 .

Bevc M (1993). Rates of return to investment in education in former Yugoslavia in the 1970s and 1980s by region. Economics of Education Review 12(4): 325-343. 
Blanchard O (1997). The economics of post-communist transition. Oxford: Clarendon Press.

Blundell R, MaCurdy T (1999). Labor supply, A review of alternative approaches. in Handbook of Labor Economics 3: 1560-1695.

Blundell R, Chiappori P, Magnac T, et al. (2005). Collective labour supply, Heterogeneity and nonparticipation. IZA: 1785.

Blundell R, Ham J, and Meghir C (1987). Unemployment and female labour supply. Economic Journal 97: 44-67.

Borjas G. (2005). Labour economics. New Yoek: McGraw-Hill. $3^{\text {rd }}$ edition.

BPK (2006). Annual report 2005. Prishtina: Banking and Payment Authority of Kosova.

Brainerd E (2000). Women in transition, Changes in gender wage differentials in Eastern Europe and the former Soviet Union. Industrial and Labor Relation Review 54(1): 138-162.

Brown S, Sessions J (2001). Actual and optimal labour supply. Applied Economics Letters 8(2): 111-113.

Bruno R (2006). Optimal speed of transition with a shrinking labour force and under uncertainty. Economics of Transition 14(1): 69-100.

Byrne D, Strobl E (2004). Defining unemployment in developing countries: evidence from Trinidad and Tobago. Journal of Development Economics, 73(1), 465- 476. http://dx.doi.org/10.1016/j.jdeveco.2002.12.005

Cameron A, Triedi P (2005). Microeconometrics: Methods and applications. New York: Cambridge University Press.

Chase R (1995). Women's labour force participation during and after communism: A case study of the Czech Republic and Slovakia. Economic Growth Centre 768.

Connolly S (1997). A model of female labour supply in which supply is dependent upon the chances of finding a job. Applied Economics 29(10): 1379-1386.

Devereux P (2004). Changes in relative wages and female labor supply. The Journal of Human Resources. XXXIX(3): 696-722.

Dutta J, Sefton J, and Weale M (1999). Education and public policy. Fiscal Studies 20(4): 351-386.

Euwals R, Van Soest A (1999). Desired and actual labour supply of unmarried men and women in the Netherlands. Labour Economics 6(1): 95-118.

Funkhauser E (1992). Migration from Nicaragua: Some recent evidence. World Development 20(8): 1209-1218.

Garrido L, Toharia L (2004). What does it take to be (counted as) unemployed? The case of Spain. Labour Economics 11: 507- 523.

Giannelli G, Monfardini C (2000). Joint decisions on household membership and human capital accumulation of youths: The role of expected earnings and local markets. IZA 191.

Green W (2003). Econometric analysis. New Jersey: Prentice Hall International Inc. $5^{\text {th }}$ edition.

Gutièrrez-Doménech M, Bell B (2004). Female labour force participation in the UK: Evolving characteristics or changing behaviour?. Bank of England: 1368-5562.

Ham J (1982). Estimation of a labour supply model with censoring due to unemployment and underemployment. Review of Economic Studies XLIX: 335354.

Hashi I (2001). The international experience of privatisation and lessons for Kosova. Staffordshire University Business School Working paper 2001.12.

Heckman J (1993). What has been learned about labor supply in the past twenty years?. American Economic Review 83(2): 116-121. 
Hussmanns R, Mehran F, and Verma V (1990). Surveys of economically, active population, employment, unemployment, and underemployment: An ILO manual on concepts and methods. International Labour Office.

ILO (1982). Resolution concerning statistics of the economically active population, employment, unemployment, and underemployment. Thirteenth International Conference of Labour Statisticians.

ILO (2005). Key indicators of the labour market. Geneva: International Labour Organisation, $4^{\text {th }}$ edition.

Jaumotte F (2003). Female labour force participation: Past trends and main determinants in OECD countries. OECD Economics department working paper 376.

Jones S, Riddell W (1999). The measurement of unemployment: An empirical approach. Econometrica 67(1): 147-162.

Kahn S, Lang K (1991). The effect of hours constraints on labour supply estimates. Review of Economics and Statistics, 73(4): 605-611.

Killingsworth M, Heckman J (1986). Female labour supply. Handbook of Labor Economics 1A: 3-102.

Kingdon G, Knight J (2000). Are searching and non-searching unemployment distinct states when unemployment is high? The case of South Africa. Centre for the Study of African Economies Working paper 2000-2.

Knowles S, Lorgelly P, and Owen D (2002). Are educational gender gaps a brake on economic development? Some cross-country empirical evidence. Oxford Economic Papers 54(1): 118-149.

Kingdon G, Knight J (2006). The measurement of unemployment when unemployment is high. Labour Economics 13: 291-315.

Konica N, Filer R (2005). Albanian emigration: Causes and consequences. IZA Annual Migration Meeting 20 May 2006.

Kornai J (2006). The great transformation of Central Eastern Europe: Success and disappointment. Economics of Transition 14(2): 207-244.

Kottis A (1990). Shifts over time and regional variation in women's labor force participation rates in a developing country: The case of Greece. Journal of Development Economics 33: 117-132.

Kuismanen M (1997). Labour supply, unemployment and income taxation: An empirical application. Government Institute for Economic Research mimeo.

Lee K, Cho K (2005). Female labour force participation during economic crises in Argentina and the Republic of Korea. International Labour Review 144(4): 423449.

Losa F, Origoni P (2005). The social-cultural dimension of women's labour force participation choices in Switzerland. International Labour Review 144(4): 476-494.

Mizala A, Romaguera P, and Henríquez P (1999). Female Labor Supply in Chile. Centre for Applied Economics mimeo.

Moalla-Fetini R, Hatanpää H, Hussein, et al. (2005). Kosovo: Gearing policies toward growth and development. Washington. International Monetary Fund.

Nesporova A (2001). Unemployment in transition economies. Geneva: International Labour Office.

OECD (1995). Supplementary measures of labour market slack: An analysis of discouraged and involuntary part-time workers. Employment Outlook 2: 43-97.

Orazem P, Vodopivec M (1997). Unemployment in Eastern Europe, value of human capital in transition to market: evidence from Slovenia. European Economic Review 41: 893-903.

Pastore F (2005). To study or to work? Education and labour market participation of young people in Poland. IZA 1793. 
Pencavel J (1986). Labour supply of men: A survey. Handbook of Labor Economic 1A: 3-102.

Riinvest Institute (2003). Labour market and unemployment in Kosova. Prishtina: Riinvest Institute.

Roland G, Verdier T (1999). Transition and the output fall. Economics of Transition 7(1): 1-28.

Saget C (1999). The determinants of female labour supply in Hungary. Economics of Transition 7(3): 575-591.

Siliverstovs B, Koulikov D (2003). Labor Supply of Married Females in Estonia. German Institute for Economic Research 321.

SOK (2004). Kosova in figures 2004. Prishtina: Statistical Office of Kosova.

SOK (2005). Statistics on education in Kosova in 2002-2003. Prishtina: Statistical Office of Kosova.

Stern N (1986). On the specification of labour supply functions. In: Blundell R, Walker I (eds) Unemployment, Search and Labour Supply. Cambridge: Cambridge University Press, 143-189.

Suryadarma S, Suryahadi A, and Sumarto S (2005). The measurement and trends of unemployment in Indonesia: The issue of discouraged workers. SMERU Research Institute 331.

Svejnar J (1999). Labour markets in transition Central and East European Countries. In Ashenfelter O, Card D (eds.) Handbook of Labor Economics 3(A). Amsterdam: North Holland, 2809-2857.

Van Ham M, Büchel F (2004). Females' willingness to work and the discouragement effect of a poor local childcare provision. IZA 1220.

Verbeek M (2004). A guide to modern econometrics. Chichester: John Wiley \& Sons LTD.

WIIW. (2007). Economic data for SEE. Available at: http://www.wiiw.ac.at/balkan/ data.html.

Wooldridge J (2002). Econometric analysis of cross section and panel data. Cambridge: The MIT Press. 


\section{Appendixes}

Table A1. Labour Force Participation Rates by Gender, Residence, Age, Education, Marital Status and Region in Kosova (2002), (individuals aged 16-64)

\begin{tabular}{|c|c|c|c|c|}
\hline & $\begin{array}{c}\text { Total } \\
\text { observations }\end{array}$ & $\begin{array}{l}\text { In the } \\
\text { labour } \\
\text { force }\end{array}$ & $\begin{array}{l}\text { Out of the } \\
\text { labour force }\end{array}$ & LFP rate \\
\hline & {$[1]$} & {$[2]$} & {$[3]$} & $\lceil 4]=[2] /[$ \\
\hline \multirow{2}{*}{\multicolumn{5}{|c|}{ By gender }} \\
\hline & & & & \\
\hline Males & 2,397 & 1,829 & 568 & 0.763 \\
\hline Females & 2,540 & 1,032 & 1,508 & 0.406 \\
\hline \multicolumn{5}{|l|}{ By residence } \\
\hline Urban & 2,244 & 1,391 & 853 & 0.620 \\
\hline Males & 1,069 & 829 & 240 & 0.775 \\
\hline Females & 1,175 & 562 & 613 & 0.478 \\
\hline Rural & 2,693 & 1,470 & 1,223 & 0.546 \\
\hline Males & 1,328 & 1,000 & 328 & 0.753 \\
\hline Females & 1,365 & 470 & 895 & 0.344 \\
\hline \multicolumn{5}{|l|}{ By age groups } \\
\hline $16-24$ & 1537 & 791 & 746 & 0.515 \\
\hline $25-34$ & 1234 & 845 & 389 & 0.685 \\
\hline $35-44$ & 956 & 650 & 306 & 0.680 \\
\hline $45-54$ & 705 & 417 & 288 & 0.591 \\
\hline $55-64$ & 505 & 158 & 347 & 0.313 \\
\hline \multicolumn{5}{|l|}{ By education } \\
\hline Less than primary & 253 & 47 & 206 & 0.186 \\
\hline Primary and lower- & 1,729 & 720 & 1,009 & 0.416 \\
\hline Upper-secondary & 2,380 & 1641 & 739 & 0.689 \\
\hline Higher & 554 & 444 & 110 & 0.801 \\
\hline No answer & 21 & 9 & 12 & - \\
\hline \multicolumn{5}{|l|}{ By marital status } \\
\hline Single & 1,696 & 986 & 710 & 0.581 \\
\hline Married & 3,078 & 1,815 & 1,263 & 0.590 \\
\hline Divorced & 21 & 15 & 6 & 0.714 \\
\hline Widowed & 133 & 43 & 90 & 0.323 \\
\hline No answer & 9 & 2 & 7 & - \\
\hline \multicolumn{5}{|l|}{ By region } \\
\hline Prishtina & 1,433 & 801 & 632 & 0.559 \\
\hline Prizren & 870 & 506 & 364 & 0.582 \\
\hline Peja & 495 & 270 & 225 & 0.545 \\
\hline Mitrovica & 845 & 531 & 314 & 0.628 \\
\hline Giilan & 600 & 346 & 254 & 0.577 \\
\hline Ferizaj & 445 & 260 & 185 & 0.584 \\
\hline Gjakova & 249 & 147 & 102 & 0.590 \\
\hline
\end{tabular}

Source of data: Riinvest HLFS of December 2002. 
Table A2. The Characteristics of the Sample used in Estimations of the Determinants of LFP (all data in the table are in proportions, unless otherwise is stated)

\begin{tabular}{lccc}
\hline Variables & All & In the labour & Inactive \\
\hline & {$[1]$} & {$[2]$} & {$[3]$} \\
\hline In the labour force & 0.61 & 1.00 & 0.00 \\
Personal characteristics & & & \\
Gender (males) & 0.49 & 0.65 & 0.23 \\
Age (years) & 35.84 & 34.21 & 38.41 \\
Age squared & $1,452.5$ & $1,299.58$ & $1,694.2$ \\
Education: less than upper-secondary & 0.45 & 0.28 & 0.71 \\
Education: upper-secondary & 0.45 & 0.57 & 0.26 \\
Education: higher & 0.10 & 0.15 & 0.03 \\
Married & 0.69 & 0.66 & 0.72 \\
Female age 25-40 & 0.22 & 0.17 & 0.30 \\
Household characteristics & & & \\
Residence (urban) & 0.45 & 0.49 & 0.39 \\
A household member is emigrant & 0.21 & 0.18 & 0.25 \\
Household labour incomes capita & 35.82 & 35.10 & 36.95 \\
Household non-labour incomes capita & 19.47 & 16.95 & 23.46 \\
Regional dummies & & & \\
Prishtina & 0.28 & 0.28 & 0.29 \\
Prizren & 0.15 & 0.15 & 0.17 \\
Peja & 0.12 & 0.12 & 0.12 \\
Mitrovica & 0.18 & 0.19 & 0.16 \\
Gjilan & 0.12 & 0.12 & 0.12 \\
Ferizaj & 0.09 & 0.10 & 0.09 \\
Gjakova & 0.05 & 0.06 & 0.05 \\
Observations & 4,460 & 2,731 & 1,729 \\
\hline Sorceordi
\end{tabular}

Source of data: Riinvest HLFS of December 2002; * Net of own wage if the person is employed.

Table A3. The Estimated Probability of Labour Force Participation

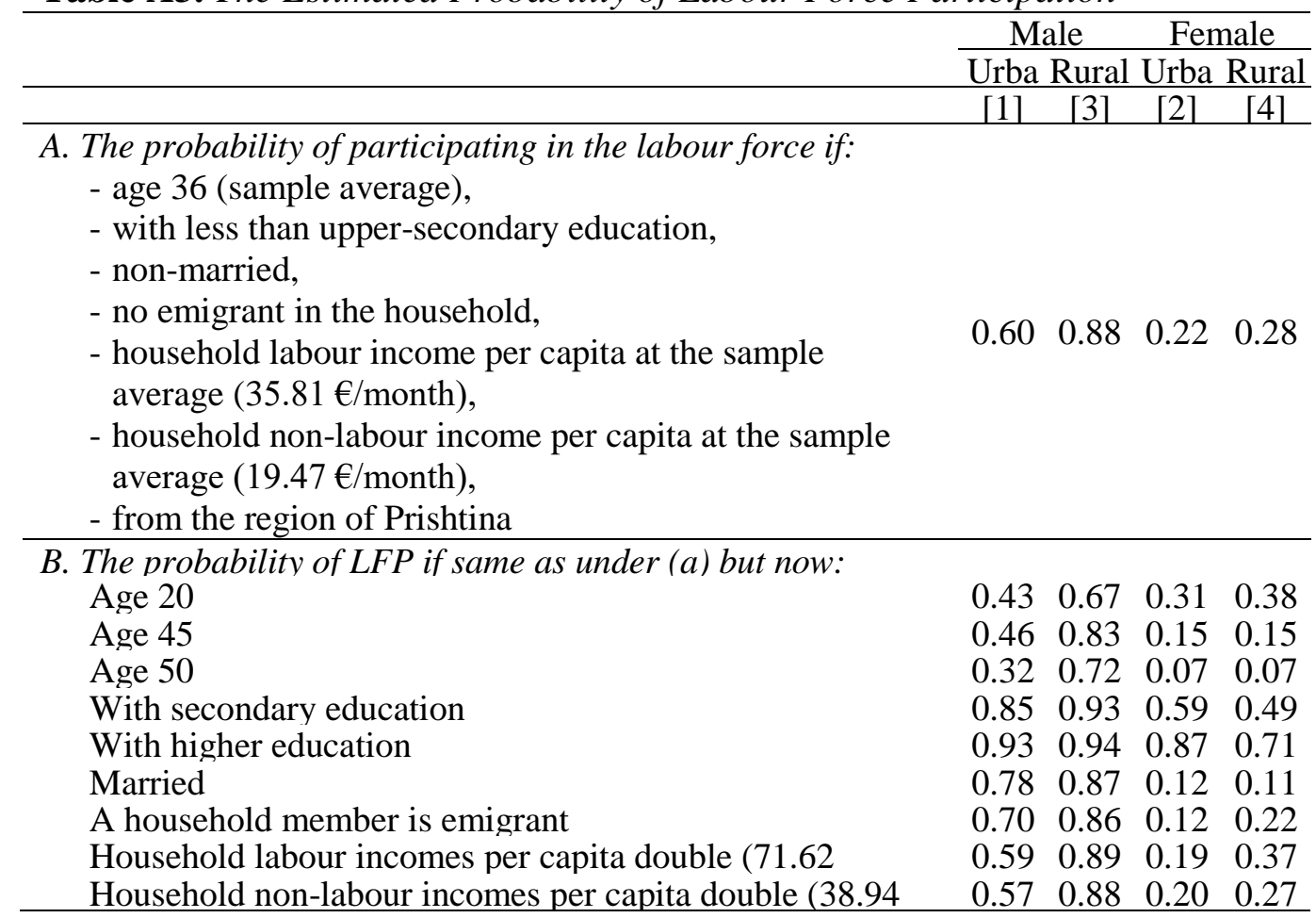


Table A4. The Main Reported Reason for not engaging in Job Search in Kosova (2002)

\begin{tabular}{|c|c|c|c|c|c|c|c|}
\hline & \multicolumn{3}{|c|}{ Number } & \multicolumn{3}{|c|}{ Proportion } \\
\hline & & \multicolumn{2}{|c|}{ Males Females } & \multicolumn{2}{|c|}{ Total Males } & \multirow{2}{*}{$\begin{array}{c}\text { Females } \\
{[5]}\end{array}$} & \multirow{2}{*}{$\begin{array}{c}\text { Total } \\
{[6]}\end{array}$} \\
\hline & & [1] & [2] & [3] & [4] & & \\
\hline A & Cannot find a job & 104 & 199 & 303 & 0.26 & 0.15 & 0.18 \\
\hline B & Not able to work & 73 & 91 & 164 & 0.18 & 0.07 & 0.09 \\
\hline $\mathrm{C}$ & Seasonal Inactivity & 4 & 3 & 7 & 0.01 & 0.00 & 0.00 \\
\hline D & Family Duties & 22 & 724 & 746 & 0.06 & 0.54 & 0.43 \\
\hline $\mathrm{E}$ & Too young or too old & 47 & 121 & 168 & 0.12 & 0.09 & 0.10 \\
\hline $\mathrm{F}$ & Enough income from remittances & 7 & 22 & 29 & 0.02 & 0.02 & 0.02 \\
\hline G & In school & 74 & 48 & 122 & 0.19 & 0.04 & 0.07 \\
\hline $\mathrm{H}$ & Retired & 26 & 21 & 47 & 0.07 & 0.02 & 0.03 \\
\hline & Other & 9 & 32 & 41 & 0.02 & 0.02 & 0.02 \\
\hline & No answer & 32 & 70 & 102 & 0.08 & 0.05 & 0.06 \\
\hline & Total & 398 & 1,331 & 1,729 & 1.00 & 1.00 & 1.00 \\
\hline
\end{tabular}

Source of data: Riinvest HLFS of December 2002; Note: The reason for not engaging in job search is in the Riinvest HLFS is asked to the inactive individuals.

Table A5. The Characteristics of the Labour Force (employed and unemployed) in Kosova (2002)

\begin{tabular}{|c|c|c|c|c|c|c|}
\hline \multirow{3}{*}{ Description } & $\begin{array}{l}\text { Labour } \\
\text { force }\end{array}$ & Employed & Unemployed & $\begin{array}{l}\text { Labour } \\
\text { force }\end{array}$ & Employed & Unemployed \\
\hline & \multicolumn{3}{|c|}{ Number of observations } & \multicolumn{3}{|c|}{ Proportion } \\
\hline & {$[1]$} & {$[2]$} & {$[3]$} & [4] & [5] & [6] \\
\hline Observations & 2,731 & 1,422 & 1,309 & 1.000 & 0.521 & 0.479 \\
\hline \multicolumn{7}{|l|}{ Age } \\
\hline $16-24$ & 661 & 189 & 472 & 1.000 & 0.286 & 0.714 \\
\hline $25-34$ & 845 & 420 & 425 & 1.000 & 0.497 & 0.503 \\
\hline $35-44$ & 650 & 387 & 263 & 1.000 & 0.595 & 0.405 \\
\hline $45-54$ & 417 & 313 & 104 & 1.000 & 0.751 & 0.249 \\
\hline $55-64$ & 158 & 113 & 45 & 1.000 & 0.715 & 0.285 \\
\hline \multicolumn{7}{|l|}{ Gender } \\
\hline Males & 1,769 & 1065 & 704 & 1.000 & 0.602 & 0.398 \\
\hline Females & 962 & 357 & 605 & 1.000 & 0.371 & 0.629 \\
\hline \multicolumn{7}{|l|}{ Residence } \\
\hline Urban areas & 1,336 & 780 & 556 & 1.000 & 0.584 & 0.416 \\
\hline Rural areas & 1,395 & 642 & 753 & 1.000 & 0.460 & 0.540 \\
\hline \multicolumn{7}{|l|}{ Level of education } \\
\hline Less than upper-secondary & 767 & 285 & 482 & 1.000 & 0.372 & 0.628 \\
\hline Upper-secondary & 1,554 & 807 & 747 & 1.000 & 0.519 & 0.481 \\
\hline Higher & 401 & 327 & 74 & 1.000 & 0.815 & 0.185 \\
\hline No answer & 9 & 3 & 6 & - & - & - \\
\hline Education (average years) & 11.26 & 11.86 & 10.62 & - & - & - \\
\hline \multicolumn{7}{|l|}{ Marital status } \\
\hline Married & 1803 & 1100 & 703 & 1.000 & 0.610 & 0.390 \\
\hline Non-married & 928 & 322 & 606 & 1.000 & 0.347 & 0.653 \\
\hline Age (average) & 34.21 & 37.67 & 30.45 & - & - & - \\
\hline
\end{tabular}

Source of data: Riinvest HLFS of December 2002. 
Figure A1: Defining the labour force status of working age population

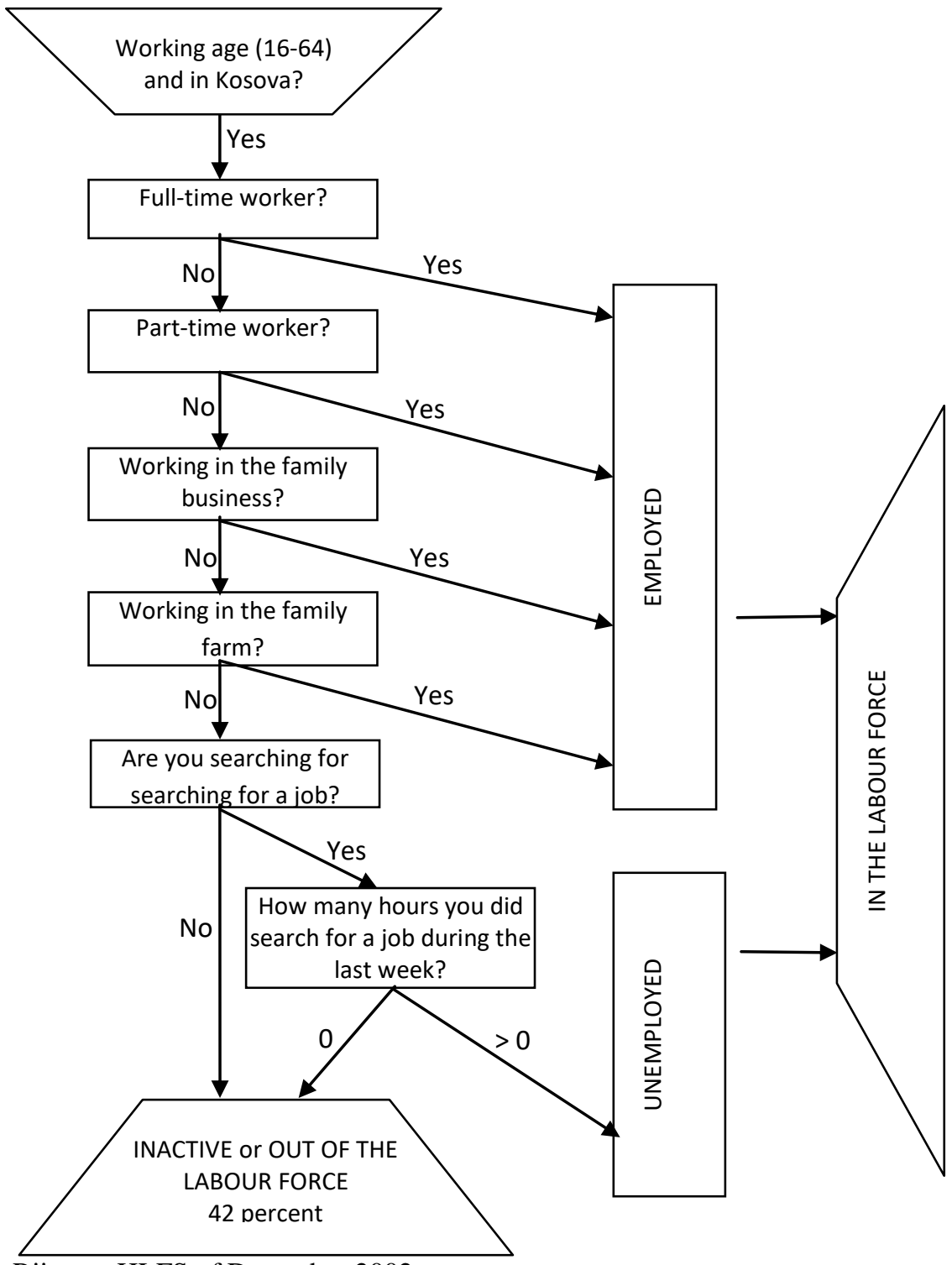

Source: Riinvest HLFS of December 2002. 